\title{
Teaching English Language through Literature
}

\author{
Nabin Chandra Marasini \\ Lecturer, Bishwa Bhasha Campus \\ Exhibition Road, Kathmandu \\ Email for correspondence: ncmarasini@gmail.com
}

\begin{abstract}
This paper seeks to examine the importance of literature in the English language classroom and looks at the effect of its use. Examples given will be mainly from personal experience gained from teaching Nepalese students. It is necessary to understand the importance of teaching English Language through literature in order to make language learning an enriching experience for students. The growing trend of learning English in Nepal has increased its significance as well. The uses of literature in the classroom explore the interesting uses of words, phrases and sounds in contexts. It, then, without human intervention increase students' awareness of literary language and help them understand language better.
\end{abstract}

Key words: literature, classroom, language, experience, awareness, understand, better, linguistic, feature

\section{The Background}

There has been a debate on different approaches for Foreign Language (FL) teaching throughout the history of language teaching. Language teachers have developed and used new and methods in the process of language teaching. Émile Durkheim states, "Language is not merely the external covering of a thought; it is also its internal framework. It does not confine itself to expressing this thought after it has once been formed; it also aids in making it" (p. 32). Similarly, teaching language through literature has been a rich source of authentic material as it conveys features of language and aesthetic beauty of language simultaneously. José Hernández Riwes Cruz says " language in use,' that is, the employment of linguistics by those who have mastered it into a fashion intended for native speakers; and aesthetic representation of the spoken language which is meant to recover or represent language within a certain cultural context" (p. 4). Literature is the mirror of every society and it incorporates subjectivity, linguistic features, grammatical patterns and aesthetic beauty. Its primary concern is to give happiness to the language learners.

After the commencement of colonization, the use of English language became a prominent tool for selling commodities to the colonized as well as non-colonized people. British Indian government ruled in India as a part of colonizer and the use of English in India, as colonized people, became an official language; and even in Nepal it affected in our daily life after the establishment of democratic 
system in 1951. The history of English language teaching in Nepal is about a half a century. The first English language education opened to the people in 1951. Earlier education was limited to the members of the royal family and there were not any public schools across the country. Krishna Bista opines, "After restoration of social equality in the nation, Tri-Chandra College started teaching English courses under the supervision of Patana University, India in the early fifties" (p. 1). Once colonization came to an end, literature of different countries gained prominence. Apart from traditional literature of English literature and American literature, literature from other parts of the world captured the imagination of readers. Right now, our students are familiar with South Asian Literature, African Literature, Asian Literature, etc.

Literary texts like poetry, story, etc is itself are about feeling and thoughts of human beings. It is a use of language to evoke a personal response in learners' mind. In Ezra Pound's words, literature is simply language charged with meaning to the utmost possible degree" (qtd. in Gillian Lazar 2). The main task of literature is to raise moral and ethical concern in the classroom. The rise of English Language Teaching (ELT), at present, has occupied functional approach of language. The revival of literature is inevitable as students find it hard to decipher the nuances of language in the ELT classroom. Various genres of literature like short stories, poems, novels, plays etc can be used effectively in the ELT classroom to make learning a joyful experience for students. The link between situation and expression has been important in language teaching; the use of literary examples in the language classroom always creates a positive atmosphere in the language classroom. T. C. Baruah expresses, "Language is always used in reference to a particular context or situation and hence the full meaning of language is known only when this situation is known' (p. 166). Unlike this, nowadays, the students are crammed inside their classroom from early morning till dusk with emphasis solely on rote learning. Due to immense pressure from higher authorities and peer groups there is a mad rush to complete the syllabus in time, which enables the students to revise and perform well in the examinations. From examination perspectives, it can give good result. The students get nothing when the context is over or they are not able to retain anything substantial once the exams get over.

ELT experts give emphasis on four major skills of language: Listening, Speaking, Reading and Writing. Through Literature, students can be taught all the four skills by paying attention to sentence structures and new vocabulary. Literature starts in delight and ends with wisdom. Literature helps students appreciate diverse cultures apart from their own cultures. In the context of Nepal, we can give examples from Gurung community, Tharu community, Magar community, etc. Once the students have absolute control over their emotions, it will help them in their professional lives. In short, one can say that literature serves a dual purpose of teaching grammatical pattern and aesthetic beauty of literature.

\section{An Appraisal}

At present every literary text is representational rather than referential. Referential language is very informational and as a result, less appealing. On the other hand, representational language appeals to one's emotions and as a result extremely interesting. Rote learning can be replaced by participative learning. Students can be encouraged to participate in parody, one act plays, presentations, etc once they have a good command over the prescribed literary texts. Joanne Collie and Stephen Slater state that the use of examples from plays, parodies, etc. create vivid pictures in the classroom. The view as, "many plays are available on records or cassettes nowadays suitable for listening experiences; in the absence

NUTA JOURNAL, 6 (1\&2), 2075 : ISSN: 2616 - 017x 
of curriculum or exam constraints, would certainly be a factor in choosing a play to read with a class" (p. 163). Literary texts for the classroom are selected based on interest and relevance to students. The level of students should be checked thoroughly before prescribing any literary texts, teaching literary texts and giving examples for teaching language. It is suggested that the texts be slightly shorter so that the students make optimum use of them before the stipulated time. Meticulous planning is necessary to ensure that the learners get literary texts that are culturally appropriate.

Alan Duff and Alan Maley raise a wide variety of questions to analyze the congruity of suggesting certain literary texts for students. They argue that selection of interesting materials, comprehensible literary examples and short and sweet examples to complete in the given time would be more important for teaching language in the context. In their views the aim of selecting easy tasks is to stimulate the interest of students. The language teacher (s) can entirely exploit the material by conducting brainstorming sessions, pre-reading tasks etc for the benefit of students. In order to draw the attention of students, teachers are expected to pay a lot of attention to pre-reading tasks, icebreakers etc. Students can be encouraged to modify the texts, change the ending etc using their creativity, ingenuity etc. Over the years, teaching language to students has undergone a sea change. Nowadays language is taught to students without the help of literature. English Language Teaching (ELT) gained prominence in Nepal after the establishment of Democratic regime in Nepal and now it is high time. Language teaching is incomplete without being familiar literature in real context. Teaching of language in isolation is not possible. The students would have solid foundation in language, if they learnt classics written literature by literary writers like Shakespeare, Wordsworth etc.

J. A. Langer states that literature plays a critical role in our life, often without our notice. It helps us to explore both ourselves and others, to define and redefine who we are, who we might become, and how the world might be in the context. In its best sense, literature is intellectually provocative as well as humanizing, allowing using various angles of vision to examine thoughts, beliefs, and actions. Langer further describes the traditional second language classroom in which literature is absent. In such classroom, learners do not have a chance to practice language through personal and meaningful engagement and are often limited to studying language in texts through low-level literal questions. Learners "are often given short passages and fill in exercises meant to develop their English skills before being provided with context that permits them to use those skills in interesting and meaningful ways" (p. 613).

Agood novel or short story can take the students to foreign countries and fantastic worlds. A play or a poem can bring up certain dilemmas and powerful emotional responses. All this can be transposed to their real lives. Literature encourages students to reflect on their own personal experiences, feelings and opinions. At the same time of learning English, they become more active, both intellectually and emotionally. Literary texts in real sense provide students to use the appropriate language according to the situation and condition. Cultural examples for teaching English are the most appropriate tool which enables the students to be familiar with the language they are studying or learning. Students will really enjoy learning culture which they firmly believe in and also accepted by society. Once the students get good command over the language doing well in campus interviews, group discussions etc. will become a cakewalk. In addition, one can say that time can be saved for students if any extra lecture in the form of career development classes and personality development classes are reduced considerably. 


\section{My Understanding}

Literature is accepted as one of the most effective resource in FL teaching. Most language teachers prefer literary texts as effective materials while some language teachers hesitate to use literary texts in their classroom. Language teachers reluctant to use literary texts in their language classrooms, but students are hesitant as well. The use of literature in the process of EFL/ESL teaching requires background language of the issues presented in these literary texts, so most of the language teachers remain skeptical and lack interest in using literature in their English lessons. We can claim that some language educators think that literature is irrelevant, who argue that what students need are texts that are 'practical' and 'rooted' in everyday experience, not works of art. The first type of language teachers are not sure about the benefit of literature and second type of language teachers ignore language in their lessons. The teacher who ignores language is not effective in teaching prepositions, tenses, and morphological, phonological, syntactical structures of the language, too.

Teaching language through literature is useful for learners as it helps the students to use their imagination and lead them to develop their own creativity. The learners try to find out what happens as events and share different or similar emotion through literary text. Literature forms interaction between learner and literary text. Rich literary texts can convey multiple meaning, and cause discussions and reflection of different feelings and opinions. This can be useful for the learners in the process of language learning. There is no doubt that literature will help the learners to get good command over the language. In other words, language is something that has to be caught and not taught. If literature is made part of the curriculum in technical education, language learning will become a really enriching experience for the students. It is clear that teaching English language through literature is viable for beginners of language learners. Literature is for all ages and never ceases to inspire the students irrespective of their age and gender.

\section{References}

Alan, D. \& Alan, M. (2007). Literature: Resource Books for Teachers. New York: Oxford University Press.

Baruah, T. C. (1992). The English Teachers' Handbook. New Delhi: Sterling Publishers.

Bista, K. (2011). Teaching English as a Foreign/Second Language in Nepal: Past and Present" English for Specific Purposes World, Issue 32, 1-9.

Collie, J. \& Slater, S. (2000).Literature in the Language Classroom: A Recourse Books of Ideas and Activities. Cambridge University Press.

Cruz, J. H. R. (2010). Role of Literature and Culture in English Language Teaching. New Delhi: Oxford Publication.

Durkheim, É. (1947). The Elementary Forms of the Religious Life. Glencoe: The Free Press.

Kansakar, T. R. (1977). The Teaching of Spoken English. Kathmandu: The First National Convention of Tribhuvan University Teachers of English.

Kramsch, C. (1998). Language and Culture. Oxford: Oxford University. 